\title{
STAFFING INNOVATIONS IN THE MUNICIPAL TERRITORY
}

\author{
Sergei A. Vorontsov ${ }^{1}$, Alexander V. Ponedelkov ${ }^{2}$
}

\begin{abstract}
This article describes a sociological analysis of the staffing issues in municipal territories. The sustainability and stability that have been ensured in recent years in almost all spheres of life are critical for Russia, which is a multinational country with a complex federative structure and diversity of cultures. The sustainability of the national economy has substantially increased, although many unsolved problems remain. The issues of an ineffective system of state and municipal governance due to employees' low professional level and corruptness are among these. This research examines the effective staffing in the municipal territories between June and August 2017. The territories are those of the Russian Federation republics of Karachay-Cherkess, Karelia, and North Ossetia-Alania; the oblasts of Volgograd, Rostov, Moscow, Arkhangelsk, Astrakhan, Kurgan, and Chelyabinsk; and krais of Krasnodar and Stavropol. Methods involve a sociological survey to assess the effectiveness of local economic policies and the proficiency of local governing bodies in securing qualified managers who are capable of innovative development. The research focuses on the effectiveness of manager rotation in the local governing bodies in the municipalities. The purpose of the research is to reveal the main obstacles to forming a staffing reserve for solving new tasks relevant to the high competitiveness of the municipal territories. It also assesses the personal qualities required of the officials in these local governing bodies and the measures needed to effectively implement investment potential and increase municipal territory competitiveness. The paper concludes with a summary of trends needed to increase the effectiveness of the municipal staff in the surveyed regions of the Russian Federation. Among the main trends are increasing the qualifications of management staff, introducing an effective staff policy, procuring a reserve of staff with the necessary qualifications, implementing effective information coverage of staff policy in the region and the municipal territories to reduce the risk of corruption, and identifying ways to motivate staff using economic incentives.
\end{abstract}

JEL Classification Number: Z18; DOI: http://dx.doi.org/10.12955/cbup.v6.1260

Keywords: state and municipal management, modernization policy, innovations, corruption, staffing.

\section{Introduction}

Almost three decades have passed since 1991, the collapse of the communist paradigm that existed in the Soviet Union. Following its failure were radical, political, economic, legal, and social reforms framed as a 'catching up Westernization' model. The beginning of the third millennium witnessed Russia's political, economic, social, and military revival. Negative tendencies leading to the country's collapse waned and the 'power vertical' and the single constitutional space were restored. In March 2014, due to a referendum conducted on the peninsula the same month, the Crimea returned to the Russian Federation.

The sustainability and stability that have been ensured in almost all spheres of life in recent years are critical for the multinational country of Russia with its complex federative structure and diversity of cultures. The national economic sustainability has substantially increased. The economy and budget dependence on energy price fluctuations have reduced. The volume of the gold reserve has risen. The inflation totals to a bit more than $2 \%$ (it is just over $2.0 \%$, whereas in 2015, inflation was $12.9 \%$ (Presidential Address to the Federal Assembly, 2018).

Although there are many unsolved problems remaining in Russia. Ineffective systems of state and municipal governance due to employees' low professionalism and corruption are among such problems. The corruptive circumstances allowed a number of people with low competencies to penetrate the governing bodies, initiate illegal mechanisms in the elite spheres, and proliferate a lack of desire for self-development (Sharkov et al., 2017).

Today, it is necessary to consider state and municipal governance in accordance with new political and economic realia. There are similar problems where, not only in Russia, but other countries, including the most prosperous, need to modernize the state apparatus, review management models and methods, and review the role and positioning of a person in the state or municipal service as a concept of 'relation among people' to intensify the 'social factor' (Joy-Metpews, 2012).

\footnotetext{
${ }^{1}$ The Russian Presidential Academy of National Economy and Public Administration, Moscow, Russia, raven_serg@mail.ru

${ }^{2}$ The Russian Presidential Academy of National Economy and Public Administration, Moscow, Russia, ponedelkov@skags.ru
} 


\section{Literature Review}

According to Bogatyreva (2013), in past years, the staffing of the municipal territories and the focus of the governing structures at the regional and local level has involved

The system of measures to reveal, to select, to prepare, to improve, to retrain and to form the reserve of the employees engaged in this sphere, this system is to be implemented on the basis of the state human resources policy. (p.90)

The adopted strategies, concepts, and programs in the Russian Federation municipalities correspond with this. The representatives of the Russian scientists, especially those from the Russian Presidential Academy of National Economy and Public Administration, support this activity. In their monographs, scientific articles, and dissertation researches, these scientists propose algorithms to solve existing problems that consider the regional peculiarities.

For example, Astakhov and Melnikova (2016) analyzed the issue of staffing in the municipal territories due to the necessity to implement strategies of their social and economic development.

Patrushev and Astakhov (2016) grounded the necessity of the innovative development of the municipal territories and the role of staff potential to achieve a modern competitive level of ensuring sustainably and advancing the development of the territories.

Pribytkova (2014) suggested, in her scientific work, that it was necessary to replace the present 'tough programmed' structures in management with those that provide prompt and flexible outcomes. According to Pribytkova, the principle of promptly forming work teams contracted to solve specific problems is the basis for these new types of management structures.

Prokofiev (2013) indicated the need for some changes in the intellectual component of the management system. To implement such, he offered training in management for developing the municipal territory on the basis of investment and as an independent sub-technology. It appeared to be an appropriate proposal, as applying such types of structures in practice in local self-governing would provide intellectually-developed staff potential for the municipal territories and serve as part of their strategic development.

The staffing issues in the municipal territories were researched in the frames of the Gaidar Forum (2018), traditionally held in the Russian Presidential Academy of National Economy and Public Administration.

Over the past five years, scientists from the Institute of Public Administration and Civil Service, together with scientists from the regional branches of the Russian Presidential Academy of National Economy and Public Administration, analyzed the problems of municipal management. Studies included analyzing effective ways of improving staff potential, related to revealing negative tendencies in the work of local authorities, and identifying adequate measures to counteract the negative tendencies. Others involved research into an optimal algorithm for the local authorities to interact with state service, civil society structures, and supervisory frameworks. Scientific conferences, 'roundtables', social studies, and surveys are considered important for identifying effective ways to staff the municipal territories.

\section{Data and Methodology}

Data were collected from a social survey of 889 experts in human resources from the Russian Federation republics of Karachay-Cherkess, Karelia, and North Ossetia-Alania; the oblasts of Volgograd, Rostov, Moscow, Arkhangelsk, Astrakhan, Kurgan, and Chelyabinsk; and krais of Krasnodar and Stavropol. The experts were surveyed while preparing for the Roundtable 'Personnel for Investment Development and Municipal Territory Competitiveness Growth (National and Foreign Practices)' by the Laboratory of Problems of Efficiency Improving of the State and Municipal Administration of the South Russian Institute of Management, which is a branch of the Russian Presidential Academy of National Economy and Public Administration (RANEPA). The specific dates were the October 27-28, 2017 in Rostov-on-Don; October 31, 2017, in Pyatigorsk; November 2, 2017 , in Kurgan; and June to August 2017 in the territories mentioned.

In respect to their profession, $46.2 \%$ of the experts identified themselves as state and municipal employees, $15.1 \%$ as entrepreneurs and part of the business community, $12.5 \%$ as involved in innovative development infrastructure, $9.2 \%$ as deputies and of political parties' activists, $9 \%$ as 
employees in education, culture, or science, and $7.3 \%$ as mass media employees. In terms of work experience, $32.5 \%$ had up to 5 years of practice, $31.2 \%$ from 5 to 10 years, $17.7 \%$ from 10 to 20 years, $12.2 \%$ from 20 to 30 years, and $6.4 \%$ had over 30 years. With regards to their permanent residence, $43 \%$ of those surveyed resided in large cities, $40.1 \%$ in small- or medium-sized cities, and $16.9 \%$ in country areas. The gender distribution was $50.7 \%$ female and $49.3 \%$ male. Those younger than 29 years of age represented $15.1 \%$, those from 30 to 39 years, $31.2 \%$; 40 to 49 years, $32.5 \%$; 50 to 59 years, $14.3 \%$; and 60 years and older, $6.9 \%$.

The social survey aimed to obtain expert opinions on the following:

- The local authorities' economic policy effectiveness;

- The state of a dialogue between local authorities and business community representatives to implement the investment potential effectively and to increase municipal territory competitiveness;

- The factors that impede, to a large extent, investment potential and an increase in municipal territory's competitiveness;

- Small and medium business support in the municipal territory through business incubators;

- Start-up support in the municipal territory;

- Coverage in the regional and local mass media of the most successful startups by young entrepreneurs in the municipal territory;

- Interaction of local authorities with scientists on business projects to improve the economic situation;

- Provision of qualified local government personnel able to ensure innovative development;

- The management personnel rotation effectiveness in the municipal territory;

- Main barriers to forming management staff reserve for solving new tasks connected with increasing the municipal territory competitiveness;

- Personal qualities required for the effectiveness of local managers;

- Role of branding in the investment development of the territory; and

- The measures to effectively implement investment potential and increase municipal territory competitiveness.

\section{Results and Discussion}

The analysis of the social survey results revealed the following main priorities.

Almost $50 \%$ of the experts assessed the local authorities' economic policy as 'absolutely effective' or 'rather effective' with some problems not being solved (Table 1). Approximately $22 \%$ rated the local authorities' economic policy as 'rather ineffective' and $17.2 \%$ as 'absolutely ineffective' with the economic situation worsening. Thus, there appears a need to make appropriate adjustments in the implementation of the local authorities' economic policy and innovations in the staffing of municipal territories.

\begin{tabular}{|r|l|l|}
\hline \multicolumn{2}{|l|}{ Table 1. Responses about local economic policy effectiveness (\%) } & 12.3 \\
\hline 1. & Absolutely effective, brings tangible results & 37.5 \\
\hline 2. & Rather effective, there are results, but some problems are not solved & 22.4 \\
\hline 3. & Rather ineffective, almost no results & 17.2 \\
\hline 4. & Absolutely ineffective, economic situation is worsening & 10.6 \\
\hline 5. & Difficult to answer & \\
\hline Source: Authors
\end{tabular}

More than a half of the experts responded that the dialogue between local authorities and business representatives was productive, in general, and only a quarter that there was a lack of dialogue (Table 2). The positive response to dialogue between local authorities and business representatives in the regions was due to the role played and the initiative of President Putin of Russia to introduce the position of Presidential Commissioner for Entrepreneurs' Rights, which is responsible for organizing the work on extrajudicial restoration of business owners' rights violated by state bodies and the settlement of arising disputes between business and authorities (Decree of the Russian Federation President of No. 879, 2012). The local institutions of the Commissioner were established in the regions, together with the Federal institutions. 


\begin{tabular}{|c|c|c|}
\hline 1. & The dialogue is very productive & 23.4 \\
\hline 2. & There is a dialogue, but there is no final agreement on some questions & 44.1 \\
\hline 3. & There is no any agreement on most issues & 22.7 \\
\hline 4. & lack of dialogue between the authorities and business community & 3.3 \\
\hline 5. & Difficult to answer & 6.5 \\
\hline \multicolumn{3}{|c|}{ Source: Authors } \\
\hline
\end{tabular}

Table 3 shows that the experts viewed the effective implementation of the investment potential and municipal competitiveness was impeded by several material factors: population's low income (36.6\%), municipal budget deficit (27.5\%); and the region's low economic development level $(19.3 \%)$.

Following these are high administrative barriers (13.7\%), unfair competition (13.1\%), mistrust to local authorities (9.2\%), and high level of corruption (8.2\%). The results of this survey shows that the experts do not highly rate the efforts of both the state and the population in fighting corruption and to introduce codes of professional ethics ('Elitogenesis').

\begin{tabular}{|c|c|c|}
\hline 1. & High unemployment level & 15.0 \\
\hline 2. & Unstable political situation// mistrust to local authorities & 9.2 \\
\hline 3. & High administrative barriers & 13.7 \\
\hline 4. & Unfair competition & 13.1 \\
\hline 5. & Inefficient purchases at the budget expense & 5.9 \\
\hline 6. & Criminogenic situation & 2.3 \\
\hline 7. & Unfavorable ecological situation & 7.8 \\
\hline 8. & The region's low economic development level & 19.3 \\
\hline 9. & Population's low income & 36.6 \\
\hline 10. & Poorly developed transport infrastructure & 9.8 \\
\hline 11. & Municipal budget deficit & 27.5 \\
\hline 12. & Shortage of qualified management personnel & 14.7 \\
\hline 13. & High level of corruption & 8.2 \\
\hline 14. & The legislative framework imperfection & 10.5 \\
\hline 15. & Small reserves of natural resources & 6.9 \\
\hline 16. & Lack of dialogue between the authorities and business community & 4.6 \\
\hline 17. & others & 0.0 \\
\hline \multicolumn{3}{|c|}{ Source: Authors } \\
\hline
\end{tabular}

Interestingly, the criminogenic threats that the experts assessed as $2.3 \%$ were considered less an issue than the threats from the corrupted state and municipal employees $(8.2 \%)$.

The experts identified industry, agriculture, trade, and natural resource extraction as industries suitable for investors (Table 4). Education (5.6\% and 7.8\%), culture (3.3\% and 6.9\%), youth policy (1.0\% and $4.2 \%)$, and sport $(7.5 \%$ and $10.1 \%)$ ranked lowest in this respect. This raises some concerns because these particular spheres substantially influence the level of training of future managerial personnel, their patriotism, and moral and volitional qualities.

About half the experts considered that the local authorities held qualified personnel or that most managerial personnel had the required qualifications (Table 5). The rest considered that either a small part of the managerial personnel only had the required qualifications or no highly qualified personnel existed in the local authorities. However, the personnel potential of any municipal territory is not isolated. It is part of the personnel potential of the region and country. However, the experts argued that there are local problems in developing the personnel potential that a normative base would solve. 


\begin{tabular}{|c|c|c|}
\hline Industries & Large investors & Small private investors \\
\hline 1. Health care & 13.1 & 11.8 \\
\hline 2. Sphere of leisure & 14.4 & 22.9 \\
\hline 3. Industry & 33.0 & 11.8 \\
\hline 4. Culture & 3.3 & 6.9 \\
\hline 5. Sport & 7.5 & 10.1 \\
\hline 6. Housing and communal services and landscaping & 9.5 & 15.0 \\
\hline 7. ecology & 8.5 & 6.2 \\
\hline 8. youth policy & 1.0 & 4.2 \\
\hline 9. education & 5.6 & 7.8 \\
\hline 10. agriculture & 27.1 & 22.2 \\
\hline 11. transport & 5.9 & 4.2 \\
\hline 12. trade & 16.0 & 18.0 \\
\hline 13. tourism & 10.5 & 19.3 \\
\hline 14. natural resources extraction & 19.9 & 11.4 \\
\hline 15. energetics & 12.1 & 4.9 \\
\hline
\end{tabular}

Table 5: Survey results on local authorities having qualified personnel (\%)

Local authorities are fully equipped with qualified personnel

Most part of the management staff have necessary qualification and professionalism

Only insignificant part of the management staff have necessary qualification

Lack of highly qualified staff in the local authorities

Difficult to answer

Source: Authors

Table 6 shows that according to the experts, modern specialists in the local self-government bodies needed knowledge on the municipal economy, legal support, human resource policy, guidelines on regulating inter-ethnic and inter-professional relations. Remarkably, the experts only identified traditional trends in the development of managerial personnel and overlooked those that are characteristic of the modern society. For example, foreign countries concentrate on high levels of computer competencies and on developing these skills for offices and in applied programs for state employees (i.e., training). Even so, only a small part of these methodologies is aimed at assessing the specific competencies related to the use of information technology by employees (Fugini, 2008).

\begin{tabular}{|l|c|}
\hline $\begin{array}{l}\text { Table 6: Survey results on directions of management personnel development in local self- } \\
\text { government bodies (\%) }\end{array}$ & 48.2 \\
\hline Project management & 10.6 \\
\hline International, interethnic and inter confessional relation regulation & 20.4 \\
\hline Municipal economy legal support & 19.1 \\
\hline Staffing policy & 1.7 \\
\hline others & \\
\hline Source: Authors & \\
\hline
\end{tabular}

Table 7: Responses to question about municipal staff reserve formation (\%)

\begin{tabular}{|l|l|c|}
\hline 1. & Yes, staff reserve is formed and consists of qualified experts & 22.4 \\
\hline 2. & staff reserve is formed, but professional level does not completely meet the requirements & 29.0 \\
\hline 3. & staff reserve is formed partially & 27.6 \\
\hline 4. & No, local authorities do not have any staff reserve & 7.9 \\
\hline 5. & Difficult to answer & 13.1 \\
\hline \multicolumn{2}{|l|}{ Source: Authors } \\
\hline
\end{tabular}

Almost $80 \%$ of experts replied that the staff reserve in the municipal territories they represent is either completely or partially formed (Table 7). However, this work requires further improvement as $13.1 \%$ of experts found it difficult to answer. Thus, it may be necessary to cover the question of staff reserve formation among wider and different strata of the population. People are expected to understand the 
legal issues regarding the functions and possibilities of self-government and the responsibilities for developing staff potential and the municipal territory as a whole.

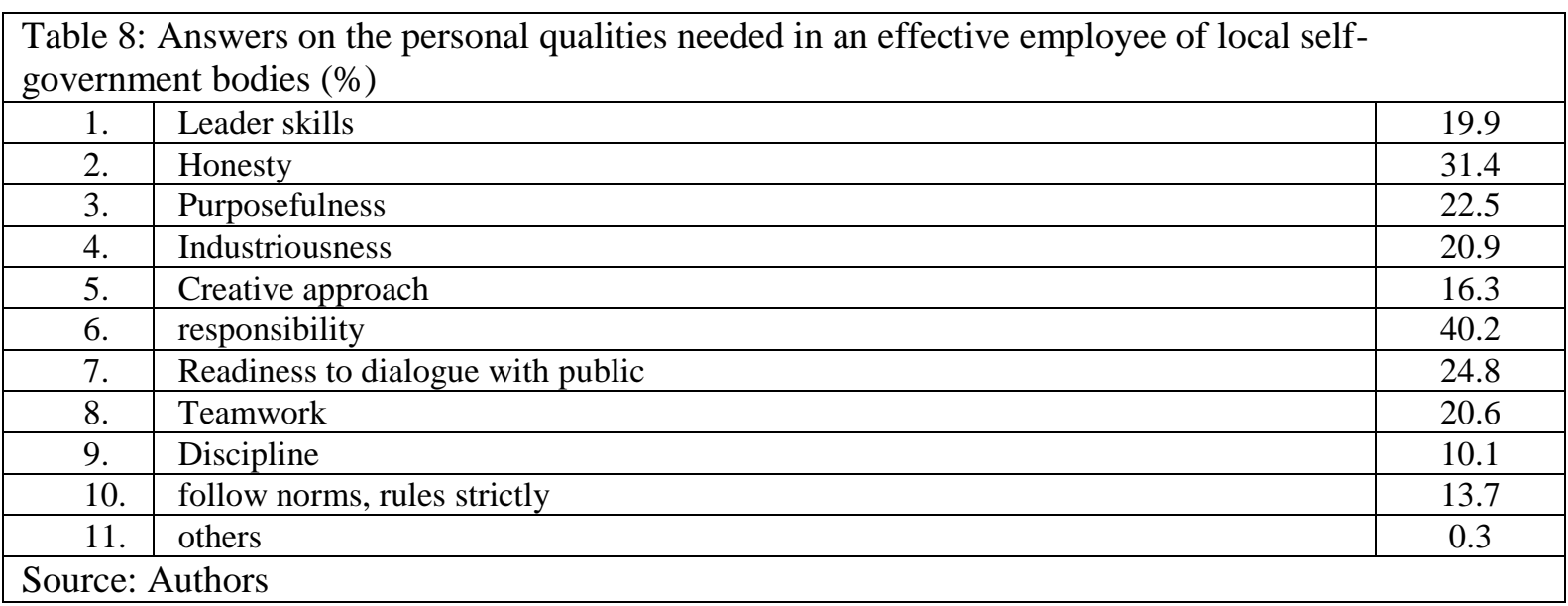

\begin{tabular}{|c|l|c|}
\hline \multicolumn{3}{|l|}{ Table 9: Answers to the expediency of the university graduates target distribution (\%) } \\
\hline 1. & Yes, it will allow forming the local government staff effectively & 42.2 \\
\hline 2. & $\begin{array}{l}\text { Rather yes, it will allow solving staff problems of local government especially for the } \\
\text { rural area }\end{array}$ & 23.2 \\
\hline 3. & $\begin{array}{l}\text { Rather no, it is applicable only for a small number or Rather no, it is applicable only for } \\
\text { a small number of university majors (for example, State and municipal management) }\end{array}$ & 12.1 \\
\hline 4. & No, such practice is not needed & 13.6 \\
\hline 5. & Difficult to answer & 8.9 \\
\hline Source: & Authors & \\
\hline
\end{tabular}

\begin{tabular}{|r|l|c|}
\hline \multicolumn{2}{|l|}{ Table 10: Responses on the measures to improve the quality of the personnel in local government (\%) } \\
\hline 1. & $\begin{array}{l}\text { Regular personnel rotation, taking into account the targeted direction for study / professional } \\
\text { retraining of promising young people, active specialists in the infrastructure of the municipal } \\
\text { territory }\end{array}$ & 27.5 \\
\hline 2. & To raise funds to retrain and to improve the qualification of the staff regularly & 15.0 \\
\hline 3. & Increase motivation of the staff with economic incentives & 35.0 \\
\hline 4. & Closer interaction with universities (internships for students, etc.) & 17.6 \\
\hline 5. & Provide population with more information on the staff reserve formation & 15.0 \\
\hline 6. & Normative and legal basis improvement to regulate the staff formation and staff reserve formation & 4.6 \\
\hline 7. & Attract scientists to find solutions to optimize staff reserve formation & 8.8 \\
\hline 8. & Fight corruption in local governments & 9.8 \\
\hline 9. & $\begin{array}{l}\text { struggle against the replenishment of the staff of local self-government bodies on the basis of kinship } \\
\text { and friendship ties }\end{array}$ & 14.1 \\
\hline 10. & Replenish the staff reserve from the citizens involved in public activity & 10.8 \\
\hline 11. & Study and apply the most successful staff reserve formation practices implemented in the Russian & 18.0 \\
\hline 12. & Federation regions as well as the foreign experience & 0.3 \\
\hline Source: Authors & \\
\hline
\end{tabular}

In rating the range of personal qualities of local government employees, the experts aimed for those that directly influenced the municipality work (Table 8 ) and identified these as responsibility $(42.2 \%)$, honesty $(31.4 \%)$, readiness to dialogue with the public (24.8\%), and purposefulness $(22.5 \%)$. Thus, the expert responses showed a preference towards executive and basic working skills, while creativity, leadership, and the ability to work in a team were less preferred. It is possible to argue that the selection of similarly 'effective' managers is not difficult and does not require a large investment in development and promotion. However, in effect, the efforts of managers can be inefficient with a staff policy oriented towards ensuring the status quo of the current situation. Where solutions are needed and risks and threats parried, these staff do not produce the expected outcomes, according to the experts dealing with the municipalities and their territories. It is also evident that the managers and specialists at the regional level are expected to excel. Moreover, their skills are expected to outperform 
those of private company employees. However, this scenario needs substantial investment and reform in the human resource area.

Table 9 shows that among the measures to increase the quality of the personnel in local government, the experts identified the necessity to raise the staff motivation through economic incentives $(35.0 \%)$. Second to this was the measure of regular personnel rotation considering the targeted area of study or professional retraining of promising young people and active specialists in the infrastructure of the municipal territory (27.5\%). The third was the study and application of the most successful staff reserve formation practices implemented in the Russian Federation regions as well as the foreign experience (18.0\%), followed by closer interaction of science and industry (17.6\%).

Almost $75 \%$ of the experts supported the targeted distribution of the higher-education graduates while $13.6 \%$ did not consider it necessary (Table 10).

\section{Conclusion}

The analysis of the experts' opinions on the above-mentioned issues shows that the main direction in raising staffing effectiveness in the Russian Federation municipalities surveyed is managerial training. First, training is needed for the management of projects, municipal economic and legal support, staffing policy, and inter-ethnic and inter-professional relationship guidelines. Increase in the effectiveness of staff policy and staff rotation are other areas. Second, there is a need to form a reserve of staff with the necessary qualifications and specialization. Third, it is recommended that the effectiveness of information coverage of personnel policy in the region and municipalities is improved to reduce the risks of corruption. Finally, it is recommended to search for ways that increase the motivation of staff by means of economic incentives and to restore the targeted distribution of university graduates.

\section{References}

Astakhov Yu.V., Melnikova R.I. (2016). Personnel Provision to implement the strategy of social and economic development of the municipal formation // Scientific bulletins of the Belgorod State University. Series: Philosophy. Sociology. Right.. 24 (245). Issue 38. - P. 34.

Bogatyreva I.V. (2013). On Some Aspects of Personnel Provision of the Municipal Service of the Region: Sociological Analysis / Scientific Bulletins of the Belgorod State University. - №2 (57). Issue 7. P. 89-96.

Decree of the Russian Federation President of 22.06.2012 No. 879 “'On the Presidential Commissioner for Entrepreneurs' Rights".

Fugini M. (2008) Why is True eGovernment still difficult to be achieved? / Fugini M., Maggiolini, P., Nanini, K., Boselli, R., Cesarini, M., Mazzanzanica M. // IFIP 20th World Computer Congress, Industry Oriented Conferences. 2008. September 710.

Gaidar forum. 2018. Access http://gaidarforum.ru/news/

Joy-Metpews D. Development of human resources. M.: Eksmo, 2012. P. 51.

Patrushev V.I., Astakhov Yu. V. Staffing of the sustainable social and economic development of the region and municipalities // Journal of "Regionology", No. 1, 2016/ URL: http://regionsar.ru/ru/node/1441.

Presidential Address to the Federal Assembly. (2018) Access https://www.1tv.ru/shows/vystupleniya-prezidentarossii/poslanie-federalnomu-sobraniyu/poslanie-vladimira-putina-federalnomu-sobraniyu-2018-polnaya-versiya

Pribytkova L.V. Local self-government: organization and self-organization // Human capital. №8. 2014. - P. 38 - 40.

Prokofiev S.E. Sustainable development of municipal territories with the use of integrated investment plans // Bulletin of the University (Gzhel State University,). No. 20, 2013. - P. 103-109.

Sharkov F.I., Ponedelkov A.V., Vorontsov S.A. On the problems of the contemporary Russian political elite and the possible directions of their resolution // Bulletin of the Russian University of Peoples' Friendship. Series: Sociology. 2017. Vol. 17. № 4. 4. P. 524-541. 